\title{
Contemporary Approaches to Physiological Adaptations after Taper Workouts
}

\author{
HALIT EGESOY'1 FATMA GÖZLÜKAYA GIRGINER ${ }^{2}$ \\ ${ }^{1}$ Faculty Sports Science, Pamukkale Unıversıty, Denizli, Turkey, halitegesoy@pau.edu.tr \\ ${ }^{2}$ Faculty Sports Scıence, Pamukkale Unıversıty, Denizli, Turkey, fgirginer@pau.edu.tr
}

\begin{abstract}
This study was conducted to systematically compile and sythesize the studies about taper training in literature and in the most current form, to reveal the physiological changes caused by taper trainings. Qualitative research methods were used for in-depth study and interpretation of the studies on taper applications published between 1985-2020. Document analysis was used as data collection method and the obtained data were analyzed by content analysis method. Taper training is a complex training method that facilitates the systematic reduction of the training load and the attainment of the physiological harmony. Before the major competitions the reductions in load, density, volume or frequency of the training in order to achieve optimal performance are made which is called the taper. The aim of taper training is to reduce fatigue and increase physiological adaptation and performance in athletes through intensive training. Since each sport branch has different physiological demands, taper trainings are applied differently in individual and team sports. The effects of these practices may vary in athletes in different branches. In the literature studies, some increases were found in the blood volume and red blood cells values, muscular glycogen deposits, some enzymes, blood lactate and VO2 max. values and the movement economies of athletes. However, in some studies, some decreases were found in the levels of the respiratory threshold, creatine kinase in the blood and the values of the submaximal ventilation, the diastolic and systolic blood pressures of the athletes.
\end{abstract}

Keywords: Taper training, athlete, performance improvement, physiological changes

\section{INTRODUCTION}

The main goal for trainers working with elite athletes is to offer a systematic and controlled training program so that the athletes can demonstrate their maximum performance in important competitions. It is very important to include taper practices in such a program $(1,2,3)$. The practice of taper strategies in elite sports is determined by daily interaction with athletes, largely based on the trainers' own observations and experiences $(4,5)$.

Today, taper training, which is used to improve performance in sports, can be defined in different ways. Taper is characterized by decreases in training capacity and / or intensity to ensure adequate recovery in athletes (6). Before important competitions, the reduction in training load, intensity, capacity or frequency in order to improve athletes' performances is called taper $(3,7,8)$. According to another definition, taper is a recovery technique used before competitions to get rid of the stress on the organism after an intensive training (9). In other words, taper training is to reduce the training intensity in order to provide physical and physiological recovery in various training periods to provide maximum competitive performance before the competition $(10,11)$. Taper is also expressed as the last step in the training program practices in the last few weeks before the competition $(8,11)$.

The term taper was first introduced in 1947 by Carlile and Cotton. In a study conducted on swimmers, Carlile and Cotton observed significant improvements in the athletes' performances when swimmers made a reduction in training intensity starting 3 weeks before the target competition after 2-3 months of hard training. They stated that these performance improvements were the result of taper practices. Taper training have continued to be practiced differently by both trainers and athletes in different periods. Fredric (1983) used the term "Zapotec Effect" to emphasize the importance of resting before the competition. Czech distance runner Emil Zapotek fell ill while training very hard for the European Games in Busseli in 1950, had to stay in the hospital for 2 weeks, and although he left the hospital just 2 days before the 10,000 meter race and could not train enough, he won the race without difficulty. Another example is that Dave Bedford was injured before the $10.000 \mathrm{~m}$ race in 1973 and he participated in the $10.000 \mathrm{~m}$ race by keeping his training at a minimum level for a few months and broke the world record in the competition (12). Until 30 years ago, there was a widespread belief that athletes should concentrate their training and do intense training before the most important races of the season. Trainers used to think that as a result of such training, the athletes would reach their maximum performance. Studies on this subject have shown that this is not the case at all. It was determined that when athletes did extensive and vigorous training for peak performance before the competition, they were tired and did not show the expected success in races (12).

How the taper practices will affect different motor performance outputs stands out as an important issue that needs to be investigated. In this context, it will be more important to try to explain physiologically and morphologically how the taper practices affects the motor performance outcomes. Because, identifying or determining possible mechanisms that might explain why the motor performance output changes will provide valuable contributions to the literature.

The aim of this study is to examine the physiological changes caused by taper training on the organism and to investigate the effects of taper training on the athletes' performances in the studies conducted in the literature. 


\section{METHOD}

In this study, qualitative research methods are used for indepth analysis and interpretation of studies about taper published between 1985-2020. Document analysis is used as the data collection method in the study, and the data obtained is analyzed by content analysis method.

The following chronological order is pursued in the review of the relevant documents in the literature; accessing documents, checking authenticity, understanding documents, analyzing data and using data. In the process of accessing documents, written and internet resources related to the subject were scanned and classified chronologically. Then, by checking the originality of the sources, the documents were analyzed in a specific system and in comparison with each other. Finally, all the data obtained were combined into a meaningful whole and the writing stage was started.

Taper Training and Muscle Energy Use: Exercise's energy cost is known as an important determinant of performance (13). If an athlete is consistently doing highcapacity training, the athlete's muscle energy stores can be expected to decline chronically. In this case, a reduction in the training volume during taper can be tolerated by an appropriate diet program. Initial muscle glycogen levels are known to have no effect on short term high intensity performance. In fact, performance decreases due to overtraining and performance rise after tapering may occur independently from muscle glycogen levels during shortterm activities $(14,15)$.

However, initial glycogen levels can affect performance during repetitive high-intensity training, as well as $60 \mathrm{~min}$ or more endurance training. Large muscle glycogen stores are essential for tapering practices for athletes. Measurements related to muscle glycogen utilization, such as lactate and aerobic enzymes, are less affected by taper. The increase in muscle glycogen stores with taper training accelerates recovery and decreases fatigue. In this case, it contributes to the improvement of the performance of athletes $(16,17,18)$.

In a study conducted on endurance athletes and by Skovgaard et. al. (2017), the athletes did an 18 day taper and then the athletes ran $10 \mathrm{~km}$. As a result of that study, it was reported that there was no change in the glycogen stores of the athletes' before and after $10 \mathrm{~km}$ run (19).

Physiological Changes in Organism as a Result of Taper

\section{Cardiovascular Changes}

Considering the relevant literature, it has been seen that taper practices have an important effect on the development of the cardiovascular and respiratory systems of athletes. Taper causes some functional and structural changes in the cardiovascular and respiratory systems of athletes, even if it is practiced for a short time.
1.1. Maximal Oxygen Consumption (VO2 max): Maximal oxygen consumption (VO2 max) is defined as the highest amount of oxygen taken up, carried and used by the body during vigorous exercise. It is accepted as the most important criterion of cardiorespiratory endurance (20). In the studies conducted with high-level athletes, it was reported that maximal oxygen consumption increased in some training related to the duration of taper, but did not show any change in others $(5,21,22,23,24)$. In a study conducted on cycling athletes about the subject, it was found that the VO2(max values of the athletes increased by $6 \%$ as a result of decreasing the weekly training intensity by $50 \%$ for 7 days. As a natural consequence of this change, an increase of $5.4 \%$ was determined in the racing performance of the athletes against $20 \mathrm{~km}$ time (25). On the other hand, in another study, as a result of applying taper training to athletes for 7 days and gradually reducing the training intensity from $30 \%$ to $80 \%$, there was no increase in the VO2 max values and performances of the athletes. For the same group, it was determined that there was an increase of $2.5 \%$ in the VO2 max values of the athletes and a $4.3 \%$ increase in their simulated performances by maintaining the training intensity and decreasing the training scope. However, in the same study, positive statistically insignificant differences were determined in VO2 max values (1.1\%) and simulated performances $(2.2 \%)$ of the athletes with the protection of the training scope and the reduction of training intensity (25). In another study on the subject, 3 different taper were practiced on 20 elite cyclists, which lasted 7 days, with 30$50 \%$ and $80 \%$ volume reductions. As a result of these different practices, it was determined that the athletes in the group with $50 \%$ volume reduction had better performance outcomes. Although the VO2 max values obtained as a result of the study were not statistically significant, it was reported that the VO2 \% max values of the athletes in the group with $50 \%$ volume reduction increased from $86.9 \%$ to $90.7 \%$ (15). In a study on elite athletes by Luden et al.(2010), the training volume was gradually reduced by $73 \%$ in the first two weeks and $50 \%$ in the third week. After the taper training, it was determined thatthere was a $0.86 \%$ decrease in the MaxVO2 values of the athletes and 3\% increase in the their performance (26). In another study held by Skovgaard et al. (2017), it was reported that there was a decrease in VO2 max values of athletes after 18-day taper practice (19).

These results, together with previous findings, show that training intensity is the key element to maintain or increase compliance with training stimuli and optimize sporting performance.

Table 1 includes studies investigating the effects of taper training practiced during exercise by sports scientists on VO2 max.

Table 1. Effects of the taper on maximal oxygen uptake (VO $2 \mathrm{max}$ )

\begin{tabular}{|l|l|l|l|l|l|}
\hline & Athletes & $\begin{array}{l}\text { Taper duration } \\
\text { (days) }\end{array}$ & VO'2max & Performance measure & $\begin{array}{l}\text { Performance } \\
\text { outcome (\%) }\end{array}$ \\
\hline Van Handel et al. (1988) & Swimmers & 20 & $\leftrightarrow$ & NR & NR \\
\hline Houmard et al. (1990) & Runners & 21 & $\leftrightarrow$ & $5 \mathrm{~km}$ indoor race & $\leftrightarrow$ \\
\hline D'Acquisto et al. (1992) & Swimmers & $14-28$ & $\leftrightarrow$ & $100 \mathrm{~m} / 400 \mathrm{~m}$ time trial & $\uparrow 4.0-8.0$ \\
\hline
\end{tabular}




\begin{tabular}{|l|l|l|l|l|l|}
\hline Jeukendrup et al. (1992) & Cyclists & 14 & $\uparrow$ & $8,5 \mathrm{~km}$ time trial & $\uparrow 7.2$ \\
\hline McConell et al. (1993) & Runners & 28 & $\leftrightarrow$ & $5 \mathrm{~km}$ time trial & $\downarrow 1.2$ \\
\hline Rietjens et al. (2001) & Cyclists & 21 & $\leftrightarrow$ & Incremental maximal test & $\leftrightarrow$ \\
\hline Dressendorfer et al. (2002) & Cyclists & 10 & $\uparrow$ & $20 \mathrm{~km}$ simulated time trial & $\uparrow 1.2$ \\
\hline Neary et al.(2003) & Cyclists & 7 & $\uparrow$ & $20 \mathrm{~km}$ simulated time trial & $\uparrow 5.4$ \\
\hline Neary et al.(2003) & Cyclists & 7 & $\uparrow$ & $40 \mathrm{~km}$ simulated time trial & $\uparrow 2.2-4.3$ \\
\hline Margaritis et al. (2003) & Triathletes & 14 & $\uparrow$ & $30 \mathrm{~km}$ time trial & $\uparrow 1.6-3.6$ \\
\hline Neary et al. (2005) & Cyclists & 7 & $\uparrow$ & $20 \mathrm{~km}$ time trial & $\uparrow 1.09$ \\
\hline Luden et al. 2010 & Runners & 21 & $\downarrow$ & $8 \mathrm{~km}$ time trial & 3 \\
\hline Skovgaard et al. 2016 & Long distance & 18 days & $\leftrightarrow$ & $10-\mathrm{km}$ time trial & $\leftrightarrow$ \\
\hline
\end{tabular}

NR = not reported; $\downarrow$ indicates decreased; $\uparrow$ indicates increased; $\leftrightarrow$ indicates unchanged ( Mujika et al.,2004

\subsection{Economy of Movement}

Movement economy is expressed as the amount of oxygen consumed during a submaximal intensity exercise. Considering the related literature, it is seen that taper practices contribute to the development of the movement economy of athletes $(27,28)$. In a study examining the submaximal energy consumption values of athletes, two groups of 18 male and 6 female distance runners, who were gradually increasing for 7 days of running and cycling, were practiced taper by reducing the total training intensity to $85 \%$. A reduction of $7 \%(0.9 \mathrm{kcal} / \mathrm{min})$ was found in the athletes' submaximal energy consumption calculated for peak oxygen consumption of $80 \%$ on the treadmill. It has been reported that this increase in the economies of movement of athletes in consequence of taper practice occurs as a result of the addition of structural and biomechanical factors together with the increase in neural speed and mitochondrial capacity in the muscles (28).

\subsection{Cardiac Function and Dimensions}

1.2.1. Resting Heart Rate: In the literature, it is seen that there are few studies on the effect of tapering on the resting heart rate of athletes. When the literature on the subject is examined, it was found that the resting heart rate of athletes did not change as a result of the taper $(29,30)$.
(Table2). In another study conducted on swimmers, it was reported that the resting heart rate of athletes did not change before and after a 2-week taper application at different levels (31).

1.2.2. Maximal Heart Rate: Considering the results of the studies investigating the effect of taper on the maximal heart rate, it was found that they were not compatible with each other. In some studies, it was reported that the maximal heart rate values of the athletes did not change, and decreased or increased in others $(32,33)$ (Table 2). In a study conducted on swimmers, it was found that after 2 and 4 weeks of different taper training, there were slight decreases in the maximal heart rate values of athletes (32). In addition, in another similar study conducted on athletes, it was determined that the maximal heart rate values of athletes did not change after the taper phase (34).

1.2.3. Submaximal Heart Rate: When the relevant literature is reviewed, it has been reported that, in a submaximal exercise, the results of some studies conducted in different sports branches in which the heart beat numbers of athletes were examined were not compatible with each other.

Table 2. Effects of the taper on heart rate $(\mathrm{HR})$

\begin{tabular}{|c|c|c|c|c|c|c|c|}
\hline Study (year) & Athletes & $\begin{array}{l}\text { Taper duration } \\
\text { (days) }\end{array}$ & $\begin{array}{l}\text { Resting } \\
\text { HR }\end{array}$ & $\begin{array}{l}\text { Maximal } \\
\text { HR }\end{array}$ & $\begin{array}{l}\text { Submaximal } \\
\text { HR }\end{array}$ & $\begin{array}{l}\text { Performance } \\
\text { measure }\end{array}$ & $\begin{array}{l}\text { Performance } \\
\text { outcome (\%) }\end{array}$ \\
\hline $\begin{array}{l}\text { Houmard et } \\
\text { al.(1990) }\end{array}$ & Runners & 21 & NR & $\uparrow$ (slightly) & $\leftrightarrow$ & $\begin{array}{l}5 \mathrm{~km} \text { treadmill time } \\
\text { trial }\end{array}$ & $\leftrightarrow$ \\
\hline $\begin{array}{l}\text { D'Acquiso et } \\
\text { al.(1992) }\end{array}$ & Swimmers & $14-18$ & NR & $\downarrow$ & $\leftrightarrow$ & $\begin{array}{l}100 \mathrm{~m} / 400 \mathrm{~m} \text { time } \\
\text { trial }\end{array}$ & $\uparrow 4.0-8.0$ \\
\hline $\begin{array}{l}\text { Jeukendrup et } \\
\text { al.(1992) }\end{array}$ & Cyclists & 14 & $\downarrow$ & $\bar{\uparrow}$ & $\uparrow$ & $\begin{array}{l}8.5 \mathrm{~km} \text { simulated } \\
\text { time trial }\end{array}$ & $\uparrow 7.2$ \\
\hline $\begin{array}{l}\text { McConell et } \\
\text { al.(1993) }\end{array}$ & Runners & 28 & $\leftrightarrow$ & $\uparrow$ (slightly) & $\leftrightarrow$ & $\begin{array}{l}5 \mathrm{~km} \text { simulated } \\
\text { time trial }\end{array}$ & $\downarrow 1.2$ \\
\hline $\begin{array}{l}\text { Houmard et } \\
\text { al.(1994) }\end{array}$ & Runners & 7 & NR & $\leftrightarrow$ & $\uparrow$ (slightly) & $\begin{array}{l}5 \mathrm{~km} \text { simulated } \\
\text { time trial }\end{array}$ & $\uparrow 2.8$ \\
\hline Stone et al.(1996) & Weightlifters & $7-28$ & $\leftrightarrow$ & NR & $\leftrightarrow$ & Competition & $\uparrow 8.0-17.5 \mathrm{~kg}$ \\
\hline Hooper et al.(1999) & Swimmers & 14 & $\leftrightarrow$ & $\uparrow$ (slightly) & NR & $100 \mathrm{~m}$ time trial & $\leftrightarrow$ \\
\hline $\begin{array}{l}\text { Martin and } \\
\text { Andersen (2000) }\end{array}$ & Cyclists & 7 & NR & $\uparrow$ (slightly) & $\leftrightarrow$ & $\begin{array}{l}\text { Incremental } \\
\text { maximal test }\end{array}$ & $\uparrow 6.0$ \\
\hline $\begin{array}{l}\text { Dressendorfer et } \\
\text { al. (2002) }\end{array}$ & Cyclists & 10 & NR & NR & $\leftrightarrow$ & $20 \mathrm{~km}$ time trial & $\uparrow 1.2$ \\
\hline Neary et al. (2003) & Cyclists & 7 & NR & NR & $\leftrightarrow$ & $\begin{array}{l}20 \mathrm{~km} \text { simulated } \\
\text { time trial }\end{array}$ & $\uparrow 5.4$ \\
\hline
\end{tabular}

NR = not reported; $\downarrow$ indicates decreased; $\uparrow$ indicates increased; $\leftrightarrow$ indicates unchanged ( Mujika et al.,2004)

1.2.4. Blood Pressure: It has been observed that there are very few studies in the literature investigating the effects of taper on blood pressure. In a study on the subject, it was found that diastolic blood pressure decreased by $2.2 \%$ and systolic blood pressure by $3.4 \%$ in swimmers (29). In another similar study, it was reported that systolic blood pressure decreased from $114 \mathrm{~mm} \mathrm{Hg}$ to 
$112 \mathrm{~mm} \mathrm{Hg}$, and diastolic blood pressure increased from $73 \mathrm{~mm} \mathrm{Hg}$ to $74 \mathrm{~mm} \mathrm{Hg}$ in runners (35).

1.2.5. Cardiac Dimensions: In a study conducted on swimmers on the subject, firstly, the athletes were trained at altitudes of $1050 \mathrm{~m}$ and $1848 \mathrm{~m}$ for 3 weeks, then through reducing the training intensity by $73 \%, 2$ weeks taper training practiced. According to the results of the study, it was determined that there was no significant change in the structural and functional states of the athletes' hearts (31).

1.3. Respiratory Function: Respiratory exchange ratio (RER) is defined as the ratio of the amount of carbon dioxide produced by the individual per unit time to the amount of oxygen consumed $(36,16)$. In the literature, there are very few studies investigating the effects of taper on respiratory function and their results are inconsistent. It was observed that there was no change in the RER value of the athletes during maximal exercises such as $20 \mathrm{~km}$ running after taper training. After 7 days of taper training combined with a high-carbohydrate diet, an increase in RER value and carbohydrate oxidation was reported after cycling exercise at $80 \%$ of VO2 max. In the same study, it was reported that the amount of oxygen inhaled by athletes decreased from $25.5 \mathrm{~L} / \mathrm{LO} 2$ to $24.0 \mathrm{~L} / \mathrm{LO} 2$ (25). In a study on endurance athletes by Skovgaard et al. (2017), a 18 days taper was done. After the taper, the athletes were tested for $10 \mathrm{~km}$ running at $60 \%$ of their V02 pace of running. It was observed that there was a decrease in athletes' RE values before and after the run (19).

1.4. Hematological Levels: Considering the literature on the subject, in a study conducted on athletes, it was reported that athletes' blood volume and red blood cells increased after taper (37). After 7 days of taper training of athletes, it was determined that there was a $15 \%$ increase in the total blood volume. It has been stated that it is caused by the increase in plasma renin and vasopressin activity during (18). In addition, in another study, it was determined that there were slight increases in haematocrit and haemoglobin concentrations during taper training for competitive swimmers (38). In addition, in another study conducted with high-level swimmers, it was found that there was a decrease in the red blood cells of athletes after 12 weeks of low-intensity and 4 weeks of high-intensity taper training (39).

1.5. Enzyme Levels: Biological catalysts in protein structure that can be synthesized by living things are called enzymes. Creatine Kinase (CK) is a type of enzyme produced in many different tissues and cells and provides body energy. The level of CK in the blood is known to be used as an indicator of training intensity. In studies on the subject, it has been reported that, during taper training, CK levels in athletes' blood decrease while athletes' oxidative enzyme and ATPase levels increase (35, 40, 41, 25). (Table 3).

1.6. Hormone Levels: Hormone is a chemical substance excreted from endocrine glands to carry out inter-cellular communication and carried to various organs and tissues by blood, regulating their structure and functions according to the needs of the body. When we look at the related literature, it has been observed in many studies that while the testosterone levels of athletes increased after taper, there was a decrease in cortisol levels $(40,42,41,10,43)$. However, in some studies, it was found that athletes had slight increases in the testosterone / cortisol ratio after taper. It has been stated that the increase in this ratio is related to the improvement in the performance of swimmers (10). Plasma nor adrenaline concentration is a marker known to be associated with recovery. However, the role of catacolamines in recovery after intense training is not fully known. In a study conducted on elite swimmers, it was determined that there was no change in plasma adrenaline, nor adrenaline and dopamine concentrations after 4 weeks of taper training (10). IGF is a hormone known as muscle growth factor. It has been reported that there is a $10 \%$ increase in the IGF value as a result of 3 weeks of intense exercises, whereas there is a $30 \%$ decrease in the IGF value after 2 weeks of taper training (44) (Table 3).

In a study conducted by Mujika and Padilla (2000) on 8 middle distance runners, a 6-day taper was implemented to athletes and it was found that there was increase in testosterone and growth hormone, while a decrease in creatine kinase level, red blood cell count and some oxidative enzyme activities (45). In a study by Frahangimalaki et al. (2009) on 24 long-distance elite cyclists, it was reported that after 3 weeks of tapering with a training intensity reduced by $50 \%$, there was an increase in athletes' performance, while a decrease in IL-1 beta, IL-6 and TNF alpha levels was observed in the third week after tapering. As a result of the study, after 2000 meters of rowing ergometer, while an $8 \%$ decrease in the leptin levels of the athletes was reported, a $9 \%$ increase in the testosterone levels was observed (46). In another similar study on the subject, 11 male athletes who did strength training were implemented a 7-day taper after an 8-week strength training program. According to the study findings, it was reported that there was no change in athletes' testerone, cortisol and creatine kinase levels (47). In the study by Skovgaard et al. (2017), after 10 days taper training, $10 \mathrm{~km}$ running test was held on the athletes and its effects on athletes' performance and muscular adaptation were investigated. As a result of this study, it was found that plasma epinephrine and norepinephrine values increased (19).

Table 3. Hematological Changes Resulting from Taper

\begin{tabular}{|l|l|l|}
\hline \multirow{5}{*}{ Hormone } & Cortisol & $\downarrow$ \\
\cline { 2 - 3 } & Testosterone & $\uparrow$ \\
\cline { 2 - 3 } & T/C Rate & $\uparrow$ \\
\cline { 2 - 3 } & IGF (3 weeks practice) & $\downarrow$ \\
\cline { 2 - 3 } & IGF (2 weeks practice) & $\downarrow$ \\
& IL-1 Beta (Practiced 3 weeks later) & \\
& IL-6 (Practiced 3 weeks later) & \\
& TNF Alfa (Practiced 3 weeks later) & \\
& Leptin & $\downarrow$ \\
\hline
\end{tabular}




\begin{tabular}{|l|l|l|}
\hline & Adrenalin & $\leftrightarrow$ \\
\hline & Nor adrenalin & $\leftrightarrow$ \\
\hline & Dopamine & $\leftrightarrow$ \\
\hline \multirow{3}{*}{ Enzyme } & Creatine kinase & $\downarrow$ \\
\cline { 2 - 3 } & Oxidative Enzyme & $\uparrow$ \\
\cline { 2 - 3 } & ATPase & $\uparrow$ \\
\hline Energy & Muscle Glycogen & $\uparrow$ \\
\hline
\end{tabular}

NR = not reported; $\downarrow$ indicates decreased; $\uparrow$ indicates increased; $\leftrightarrow$ indicates unchanged

\section{Metabolic Changes}

\subsection{Blood Lactate Kinetics}

2.1.1. Maximal Exercise: Studies on the subject in the literature show that as a result of taper training, there are significant increases in the blood lactate concentrations of athletes after maximal exercise $(24,32,48,37)$. (Table 4). It is stated that this change, which may be associated with the increase in muscle glycogen stores after taper, may cause an increase in the maximal performance capacity of athletes (28). In a study conducted on male cyclists on the subject, a 14-days taper training was implemented to athletes and it was found that the blood lactate concentrations of athletes increased by $78 \%$. In addition, in the $8.5 \mathrm{~km}$ (outdoor time trial) race, it was determined that there was an improvement of $7.2 \%$ in the athletes' performances and $10.3 \%$ in their maximal power output.

2.1.2. Submaximal Exercise: Considering the studies conducted on the subject in the literature, it has been determined that there are inconsistent changes in the intensity of submaximal exercise and the blood lactate concentrations of athletes $(49,32,34,50)$ (Table 4). In a study on the subject, after 2 and 4 weeks of taper implemented to high school female athletes, it has been determined that the blood lactate levels during submaximal intensity swimming exercise decreased between $15-26 \%$ in the 2-week taper, and $26-33 \%$ in the 4-week taper. (30). In addition, in another study, it was reported that the blood lactate concentrations of athletes did not change in exercises at submaximal intensity $(75 \%$ for runners and $90 \%$ for swimmers) after the taper phase (35). In their studies, Skovgaard et al. (2017), they conducted $10 \mathrm{~km}$ running test on athletes after 18 days of taper. They took blood from the athletes and examine the blood lactate values before and after the test. It was observed that in the blood taken 3 minutes after the end of the test, the blood lactate levels of the athletes decreased significantly (19).

Table 4. Effects of the taper on blood lactate concentration (H[La])

\begin{tabular}{|c|c|c|c|c|c|c|}
\hline Study (year) & Athletes & $\begin{array}{l}\text { Taper } \\
\text { duration } \\
\text { (days) }\end{array}$ & Peak H[La] & $\begin{array}{l}\text { Submaksimal } \\
\text { (H[La]) }\end{array}$ & $\begin{array}{l}\text { Performance } \\
\text { measure }\end{array}$ & $\begin{array}{l}\text { Performance } \\
\text { outcome (\%) }\end{array}$ \\
\hline $\begin{array}{l}\text { Costill et al. } \\
(1985)\end{array}$ & Swimmers & 14 & NR & $\downarrow$ & $\begin{array}{l}46-1509 \mathrm{~m} \\
\text { Competition }\end{array}$ & $\uparrow 2.2-4.6$ \\
\hline $\begin{array}{l}\text { D'Acquisto et al. } \\
\text { (1992) }\end{array}$ & Swimmers & 14-28 & $\bar{\uparrow}$ & $\downarrow$ & $\begin{array}{l}100 \mathrm{~m} \\
\text { time trial }\end{array}$ & $\uparrow 4.0-8.0$ \\
\hline $\begin{array}{l}\text { Jeukendrup et } \\
\text { al. (1992) }\end{array}$ & Swimmers & 14 & $\bar{\uparrow}$ & NR & $\begin{array}{l}8.5 \mathrm{~km} \text { outdoor } \\
\text { time trial }\end{array}$ & $\uparrow 7.2$ \\
\hline $\begin{array}{l}\text { Johns et al. } \\
(1992)\end{array}$ & Swimmers & $10-14$ & NR & $\leftrightarrow$ & $\begin{array}{l}\text { 46-366 m } \\
\text { Competition }\end{array}$ & $\uparrow 2.0-3.7$ \\
\hline $\begin{array}{l}\text { McConell et } \\
\text { al.(1993) }\end{array}$ & Runners & 28 & NR & $\uparrow$ & $\begin{array}{l}5 \mathrm{~km} \text { indoor time } \\
\text { trial }\end{array}$ & $\downarrow 1.2$ \\
\hline $\begin{array}{lll}\begin{array}{l}\text { Flynn } \\
(1994)\end{array} & \text { et } & \text { al. } \\
\end{array}$ & Swimmers & 21 & NR & $\leftrightarrow$ & $\begin{array}{l}23-366 \quad m \quad \text { time } \\
\text { trial }\end{array}$ & $\uparrow 3.0$ \\
\hline Kenitzer (1998) & Swimmers & $14-28$ & NR & $\begin{array}{l}\downarrow 14 \text { days } \\
\uparrow 21-28 \text { days }\end{array}$ & $\begin{array}{llc}4 & \times \quad 91 & m \\
\text { submaksimal set }\end{array}$ & $\uparrow 4.0$ \\
\hline $\begin{array}{l}\text { Steinacker et } \\
\text { al.(2000) }\end{array}$ & Rowers & 7 & $\uparrow$ (slightly) & NR & $2000 \mathrm{~m}$ & $\uparrow 6.3$ \\
\hline $\begin{array}{l}\text { Rietjens et al. } \\
(2001)\end{array}$ & Cyclists & 21 & NR & $\leftrightarrow$ & $\begin{array}{l}\text { Incremental } \\
\text { maximal test }\end{array}$ & $\leftrightarrow$ \\
\hline $\begin{array}{ll}\text { Mujika } & \text { et } \\
\text { al.(2002) } & \end{array}$ & Runners & 6 & $\bar{\uparrow}$ & $\mathrm{R}$ & $\begin{array}{l}800 \mathrm{~m} \\
\text { Competition }\end{array}$ & $\uparrow 0.4-1.9$ \\
\hline $\begin{array}{l}\text { Skovgaard ve } \\
\text { ark., } 2017\end{array}$ & Runners & 18 & NR & $\downarrow$ & $10 \mathrm{~km}$ time trial & $\uparrow 2.7$ \\
\hline
\end{tabular}

NR = not reported; $\downarrow$ indicates decreased; $\uparrow$ indicates increased; $\leftrightarrow$ indicates unchanged ( Mujika et al.,2004)

\subsection{Muscle Glycogen Levels}

In the literature, some changes have been observed in the muscle glycogen concentrations of athletes after taper training $(41,15,51)$. In a study on the subject, it was reported that the muscle glycogen storage of athletes increased by $25 \%$ after a taper lasting 8 days, and by $17 \%$ after a 4-day taper (15). In another study, it was found that the increase in glycogen stores of female athletes after taper was higher than that of male athletes (52).

\section{Neuromuscular Changes}

\subsection{Strength and Power}

According to the studies conducted, it was found that there are significant improvements in strength and power levels of athletes as a result of the taper training $(53,16,11,54$, $55,56,57)$ (Table 5$)$. In a study conducted on swimmers in which strength and power output were examined, it was determined that after a 2-week taper, there was an increase of $18 \%$ in arm strength measured in accordance 
with the swimming biokinetics of athletes and a $25 \%$ increase in current swimming strength (in distance). At the same time; It was also reported that as a result of this increase in arm strength measured biomechanically, there was an increase of $3.1 \%$ in performance of athletes in the general competition (49). Similar results were obtained in another study conducted on cyclists. As a result of the incremental maximal test applied to cyclists after taper, it was determined that there was an $8.0 \%$ improvement in the performance levels of the athletes (58).

In a study by Izquerdo et al. (2007) on 11 physically active men, a taper training was implemented for 4 weeks following 16 weeks of strength training, and it was reported that there were $2 \%-3 \%$ increases in the bench press and squat strength of athletes (42). In another similar study, it was stated that there was an increase of $5-6 \%$ in the running distance of distance runners after taper training (8). In the study conducted by Grgic and Mikulic (2017) on 10 powerlifting champions, athletes did taper training for 8 to 2 days before the championship with an average reduction of $50 \%$ in training intensity. All athletes stated that taper training applied before the competition positively affected their performance during the competition (59). In the study by Pritchard et al. (2018) on 11 athletes, taper was implemented to the athletes for 7 days after intensive work. It was determined that there was a statistically significant improvement in the athletes' vertical jump performanceand the contraction times during jumping. In the same study, it was reported that athletes had an increase in bench press strength and isometric mid-thigh pull strength (47).

In a study conducted by Vachon et al (2020), the effects of taper on the metabolic fitness and nervous muscular system of athletes who do team sports were examined by using meta-analysis. As a result of this study, the researchers found that there was an increase in the repetitive sprint performance $((\mathrm{SMD})(95 \% \mathrm{IC} ; \mathrm{I} 2)=0.41)$, maximal power $((\mathrm{SMD}(95 \% \mathrm{IC} ; \mathrm{I} 2)=0.44)$, and direction change speed $((\operatorname{SMD}(95 \% \mathrm{IC} ; \mathrm{I} 2)=0.38) 60)$.

Table 5. Effects of the taper on muscular strength and power

\begin{tabular}{|c|c|c|c|c|c|}
\hline Study (year) & Athletes & $\begin{array}{l}\text { Taper duration } \\
\text { (days) }\end{array}$ & $\begin{array}{l}\text { Strength and/or } \\
\text { power }\end{array}$ & Performance measure & $\begin{array}{l}\text { Performance } \\
\text { outcome (\%) }\end{array}$ \\
\hline Costill et al. (1985) & Swimmers & 14 & $\uparrow$ & $\begin{array}{l}46-1509 \mathrm{~m} \\
\text { Competition }\end{array}$ & $\uparrow 2.2-4.6$ \\
\hline $\begin{array}{l}\text { Cavanaugh and } \\
\text { Musch (1989) }\end{array}$ & Swimmers & 28 & $\bar{\uparrow}$ & $\begin{array}{l}46-1509 \mathrm{~m} \\
\text { Competition }\end{array}$ & $\uparrow 4.0-8.0$ \\
\hline Johns et al. (1992) & Swimmers & $10-14$ & $\bar{\uparrow}$ & $\begin{array}{l}46-366 \mathrm{~m} \\
\text { Competition }\end{array}$ & $\uparrow 2.0-3.7$ \\
\hline Shepley et al.(1992) & Runners & 7 & $\uparrow$ & Treadmill time trial & $\uparrow 6.0-22.0$ \\
\hline Martin et al. (1994) & Cyclists & 14 & $\uparrow$ & Incremental maximal test & $\uparrow 8.0$ \\
\hline Trappe et al.(2000) & Swimmers & 21 & $\uparrow$ & Competition & $\uparrow 3.0-4.7$ \\
\hline Zaras et al. (2014) & Runners & 7 & $\uparrow$ & Strength performance & $\uparrow 5.0-6.0$ \\
\hline $\begin{array}{l}\text { Pritchard et } \\
\text { al.(2018) }\end{array}$ & $\begin{array}{l}\text { Strength } \\
\text { trained }\end{array}$ & 5 & $\uparrow$ & İsometric bench press & $\uparrow 1.0-4.0$ \\
\hline $\begin{array}{l}\text { Pritchard et } \\
\text { al.(2018) }\end{array}$ & $\begin{array}{l}\text { Strength } \\
\text { trained }\end{array}$ & 5 & $\bar{\uparrow}$ & İsometric mid-thigh pull & $\uparrow 2.0-3.0$ \\
\hline $\begin{array}{l}\text { Hermassi et } \\
\text { al(2019) }\end{array}$ & Handball & 14 & $\bar{\uparrow}$ & Lower limbs & $\uparrow 12.1$ \\
\hline $\begin{array}{l}\text { Hermassi et } \\
\text { al(2019) }\end{array}$ & Handball & 14 & $\bar{\uparrow}$ & Bench pres & $<0.001$ \\
\hline $\begin{array}{l}\text { Hermassi et } \\
\text { al(2019) }\end{array}$ & Handball & 14 & $\bar{\uparrow}$ & Running shot (m/s) & $<0.001$ \\
\hline $\begin{array}{l}\text { De Lacey at } \\
\text { al.(2014) }\end{array}$ & Rugby & 21 & $\uparrow \uparrow$ & Jump height & $\uparrow 35$ \\
\hline Rhibi et al. (2016) & $\begin{array}{l}\text { Sedentary } \\
\text { (28 man) }\end{array}$ & 14 & $\uparrow$ & Counter-movement jump & $\uparrow 5$ \\
\hline $\begin{array}{l}\text { Pitchhard et } \\
\text { al.(2018) }\end{array}$ & $\begin{array}{l}\text { Strength } \\
\text { trained }\end{array}$ & 5 & $\uparrow \uparrow$ & Counter-movement jump & $\bar{\uparrow}$ \\
\hline $\begin{array}{l}\text { Hermassi et } \\
\text { al(2019) }\end{array}$ & Handball & 14 & $\bar{\uparrow}$ & Counter-movement jump & $\uparrow 4$ \\
\hline
\end{tabular}

$\downarrow$ indicates decreased; $\uparrow$ indicates increased; $\leftrightarrow$ indicates unchanged ( Mujika et al.,2004)

\section{Changes in Muscle Fibre \\ 4.1. Muscle Fibre Size}

In the literature, it has been reported that there are some changes in athletes' fibril structure as a result of taper (61, $62,63,64,65)$. In a study conducted on male swimmers, it was found that after a 3-week taper, there was no change in athletes' type 1 fibre diameter and in crosss-sectional area, but type $2 \mathrm{a}$ fibre diameter increased by $11 \%$ and cross-sectional area increased by $24 \%$ (65). In another study, 7-day high intensity (85-90\% of maximal HR) and low volume (gradually decreasing from 60 minutes to 20 minutes) taper were implemented on male cyclists. It was observed that athletes had an increase of $6.9 \%$ in type 1 fibres' cross-sectional area and a 14\% increase in type 2 fibres' cross-sectional area. In a low intensity (maximal HR gradually decreasing from $85 \%$ to $55 \%$ ) and high density (60 min for each unit), a 7\% increase in type 1 fibres of athletes and an $11 \%$ increase in type 2 fibres were detected (25). Luden et al. Conducted a 21 days taper study on athletes. In this taper there was a decrease in training intense of $27 \%$ in the first and second weeks; and $50 \%$ on the third week. After taper, it was reported that $15 \%$ growth was observed in athletes' type 2 fibril diameter, while a $7 \%$ increase in the type 2 fibril strength. 
In another similar study conducted on professional volleyball players, it was found that athletes' jumping performance did not change after the taper training by reducing the volume by $20 \%-40 \%$, but there was a decrease in the diameter of the quadriceps muscle fibres and that these levels were better than the pre-season values. On the other hand, it has been reported that there is no change in muscle fascicle length, pennation angle (angle of incidence of muscle fibers into the tendon) and jump height levels (66).

\subsection{Metabolic Properties}

It has been determined that there are few studies on the subject in the literature. In a study conducted on cycling athletes, it was determined that after a high intensity/lowvolume taper, ATPase increased by $11 \%$ and succinate dehydrogenase enzyme increased by $12 \%$ in type 1 fibres. A $15-16 \%$ increase was detected in ATPase, succinate dehydrogenase, acyl-CoA dehydrogenase and cytochrome c oxidase (complex IV enzyme) enzymes in type 2 fibres. It has been determined that these changes provide a $4.3 \%$ increase in the $40 \mathrm{~km}$ bicycle racing performance of the athletes (64).

\section{CONCLUSIONS}

It has been observed that taper brings about some physiological changes in athletes' organisms and in this case it contributes to the performance improvement of athletes. Due to intense training, athletes' physiological structures deteriorate and their performance decreases. In the taper phase, the stimuli are greatly reduced, so the recovery of the athletes before important competitions is faster and their performance reaches the optimal level.

The implementation of taper strategies in elite sports is largely determined by daily interaction with athletes, based on the coaches' own observations and experiences. Trainers, who prepare elite athletes for important competitions, can create significant physiological changes in athletes with a well-designed taper program and contribute to athletes' performance improvement.

As a result of a systematic review of the limited number of studies in the literature, it may be concluded that more studies are necessary to investigate the effects of taper training on different sport branches in which both aerobic and anaerobic metabolisms are active.

\section{REFERENCES}

1. Baioumy, M.E., Ghazy, A.M. (2015). Effects of a major taper training program on some physical variables and specific fitness for judokas. Int Sci J Phy Edu Sport Sci. 2(2): 110.

2. Bishop, D., Edge, J. (2005). The effects of a 10-day taper on repeated-sprint performance in females. J Sci Med Sport. 8(2): 200-209.

3. Mujika, I. (2010). Intense training: the key to optimal performance before and during the taper. Scand J Med Sci Sports, 20, 24-31.

4. Pyne, D.B., Mujika, I., Reilly, T. (2009). Peaking for optimal performance: research limitations and future directions. J Sports Sci. 27(3): 195-202.

5. Spilsbury, K.L., Fudge, B.W., Ingham, S.A., et al. (2014). Tapering strategies in elite British endurance runners. Eur $\mathrm{J}$ Sport Sci. 15, 1-7.

6. Freitas, C.G., Aoki, M.S., Franciscon, C.A., et al. (2014). Psychophysiological responses to overloading and tapering phases in elite young soccer players. Pediatr Exerc Sci. 26 (2): 195-202.

7. Gerald, S.Z. (2000). Evidence and possible mechanisms of altered maximum heart rate with endurance training and tapering. Sport Med, 29(1): 13-26.

8. Zaras, N., Stasinaki, A.N., Krase, A., Methenitis, S. (2014) Effects of tapering with light vs. heavy loads on track and field throwing performance. J Strength Cond Res. 28, 348495.

9. Farhangimaleki, N., Zehsaz F., Tiidus Pm. (2009). The effect of tapering period on plasma pro-inflammatory cytokine levels and performance in elite male cyclists. J Sports Sci Med. 8(4): 600-606.

10. Mujika, I., Padilla, S. (2003). Scientific bases for precompetition tapering strategies. Med. Sci. Sports Exerc. 35, 1182-87.

11. Pritchard, H., Keogh, J., Barnes, M., et al. (2015). Effects and mechanisms of tapering in maximizing muscular strength. J. Strength Cond. 37(2): 72-83.

12. Gardner, D.S. (2006). Historical progression of racing performance in thoroughbreds and man. Equine Vet J. 38(6): 581-83.

13. Di Prampero, P.E., Atchou, G., Brückner, J.C., Moia, C. (1986). The energetics of endurance running. Eur. J. Appl. Physiol. Occup. Physiol. 55, 259-66.

14. Anderson, O. (2002). Glycogen without glucose gluttony; your new carb strategy for optimum performance. Peak Perf. 170, 7-10.

15. Neary, J.P., Mckenzie, D.C., Bhambhani, Y.N. (2005). Muscle oxygenation trends after tapering in trained cyclists. Dyn Med. 24; 4(1): 4.

16. Coutts, A.J., Reaburn, P., Piva, T.J., Murphy, A. (2007) Changes in selected biochemical, muscular strength, power, and endurance measures during deliberate overreaching and tapering in rugby league players. Int. J. Sports Med. 28(2): 116-24.

17. Mujika, I. (2011). Tapering for triathlon competition. J. Human Sport Exerc. 2(6): 264-70.

18. Shepley, B., Macdougall, J.D., Cipriano, N., et al. (1992). Physiological effects of tapering in highly trained athletes. $J$ Appl Physiol. 72, 706-11.

19. Skovgaard, C., Almquist, N.W., Kvorning, T., Christensen P.M, Bangsbo, J., Effect of tapering after a period of highvolume sprint interval training on running performance , and muscular adaptations in moderately trained runners, Journal of Applied Physiology

20. Saltın, B., Astrand, P.O. (1967). Maximal oxygen uptake in athletes. J. Appl. Physiol. 23, 353-58.

21. Grivas, G.V. (2018). The effects of tapering on performance in elite endurance runners: a systematic review. Int. J. Sports Sci. 8(1): 8-13.

22. Margaritis, I.S., Palazzetti, A.S., Rousseau, M.J, et al. (2003). Antioxidant supplementation and tapering exercise improve exercise-induced antioxidant response. J. Am. Coll. Nutr. 22, 147-56.

23. Rıetjens, G.J., Keızer, H.A., Kuıpers, H., Sarıs W.H. (2001). A reduction in training volume and intensity for 21 days does not impair performance in cyclists. Br. J. Sports Med. 35, 431-34.

24. Van Handel, P., Katz, A., Troup, J., et al. (1988). Oxygen consumption and blood lactic acid response to training and taper. Swim. Sci. 269-75.

25. Neary, P., Martin, T.P., Quinney H.A. (2003). Effects of taper on endurance cycling capacity and single muscle fiber properties. Med Sci Sports Exerc, 35(11):1875-81.

26. Luden, N, et al., 2010, Myocellular basis for tapering in competitive distance runners, Journal of Applied Physiology, 108(6), 1501-1509.

27. Bosquet, L., Leger, L., Legros, P. (2002). Methods to determine aerobic endurance. Sports Med. 32, 675-700. 
28. Houmard, J.A., Scott, B.K., Justice, C.L., Chenier, T.C. (1994). The effects of taper on performance in distance runners. Med Sci Sports Exerc. 26(5): 624-31.

29. Hooper, S.L., Mackinnon, L.T., Howard, A. (1999). Physiological and psychometric variables for monitoring recovery during tapering for major competition. Med Sci Sports Exerc. 31(8): 1205-10.

30. Mcconell, G.K., Costill, D.L., Widrick, J.J., et al. (1993). Reduced training volume and intensity maintain aerobic capacity but not performance in distance runners. Int $J$ Sports Med. 14(1): 33-7.

31. Haykowsky, Mj., Smith, Dj., Malley, L., et al. (1998). Effects of short term altitude training and tapering on left ventricular morphology in elite swimmers. Can J Cardiol, 14, 67881.

32. D'acquisto, L.J., Bone, M., Takahashi, S., et al. (1992). Changes in aerobic power and swimming economy as a result of reduced training volume. Int. Swim Sci. Vı.: Mclaren D., Reilly T., Lees A., Editors. London: E And Fn Spon: 195201.

33. Martin, D.T., Andersen, M.B. (2000). Heart rate-perceived exertion relationship during training and taper. J Sports Med Phys Fitness, 40, 201-8.

34. Houmard, J.A., Kirwan, J.P., Flynn, M.G., et al. (1989). Effects of reduced training on submaximal and maximal running responses. Int J Sports Med, 10, 30-3.

35. Flynn, M.G., Pizza, F.X., Boone Jr, J.B., et al. (1994). Indices of training stress during competitive running and swimming seasons. Int J Sports Med. 15(1): 21-26.

36. Aubry, A., Hausswirth, C., Louis, J., et al. (2014). Functional overreaching: the key to peak performance during the taper? Med. Sci. Sports Exerc. 46(9): 1769-77.

37. Mujika, I., Goya, A., Ruiz, E., et al. (2002). Physiological and performance responses to a 6-day taper in middle-distance runners: Influence of training frequency. Int J Sports Med. 367-73.

38. Gledhill, N. (1985). The influence of altered blood volume and oxygen transport capacity on aerobic performance. Exerc Sports Sci Rev. 13, 75-94.

39. Mujika, I., Chatard, J.C., Geyssant, A. (1996). Effects of training and taper on blood leucocyte populations in competitive swimmers: relationships with cortisol and performance. Int J Sports Med. 17, 213-7.

40. Houmard, J.A., Costill, D.L., Mitchell, J.B., et al. (1990). Testosterone, cortisol, and creatine kinase levels in male distance runners during reduced training. Int. J. Sports Med. $11,41-45$.

41. Mujika, I., Padilla, S., Pyene, D., Busso, T. (2004). Physiological changes associated with the pre-event taper in athletes. Sports Med. 34(13): 891-927.

42. Izquierdo, M., Ibanez, J., Gonzalez-Badillo, J.J., et al. (2007). Detraining and tapering effects on hormonal responses and strength performance. J Strength Cond. Res. $21,768-75$

43. Vollaard, N.B., Cooper, C.E., Shearman, J.P. (2006). Exercise-Induced oxidative stress in overload training and tapering. Med Sci Sports Exerc. 38 (7): 1335-41.

44. Steinacker, J.M., Lormes, W., Kellmann, M., et al. (2000). Training of junior rowers before world championships: effects on performance, mood state and selected hormonal and metabolic responses. J Sports Med Phys Fitness, 40, 32735.

45. Mujika, I., Padilla, S. (2000). Detraining: loss of trainingInduced physiological and performance adaptations. Sports Med, 30(2): 79-87.

46. Maestu, J., Jurimae, J., Jurimae, T. (2003). Hormonal reactions during heavy training stress and following tapering in highly trained male rowers. Horm. Metab. Res. 35(2):10913 Epub2003/05/08.
47. Pritchard, H. J., Barnes, M. J., Stewart, R. J., et al. (2018). Higher- versus lower intensity strength-training taper: effects on neuromuscular performance. Int $\mathrm{J}$ Sports Physiol Perf, 14(4): 458-63.

48. Jeukendrup, A.E., Hesselink, M.K.C., Snyder, A.C., et al. (1992). Physiological changes in male competitive cyclists after two weeks of intensified training. Int $\mathrm{J}$ Sports Med. 13, 534-41.

49. Costill, D., King, D., Thomas, R. (1985). Effects of reduced training on muscular power in swimmers. Phys. Sports Med. 13, 94-101.

50. Kenitzer J.R, Raymond F. (1998). Optimal taper period in female swimmers. J. Swim Res. 13: 31-36.

51. Rockwell, M.S., Rankin, J.W., Dixon, H. (2003). Effects of muscle glycogen on performance of repeated sprints and mechanisms of fatigue. Int. J. Sport Nutr. Exerc. Metab. 13, $1-14$

52. Walker, J.L., Heigenhauser, G.J., Hultman, E., Spriet, L.L. (2000). Dietary carbohydrate, muscle glycogen content, and endurance performance in well-trained women. J Appl Physiol. 88(6): 2151-58.

53. Costill D.L., Thomas R., Robergs R.A., et al. (1991). Adaptation to swimming training: influence of training volume. Med. Sci. Sports Exerc. 23, 371-77.

54. Trinity, J.D., Pahnke, M.D., Reese, E.C., Coyle, E.F. (2006). Maximal mechanical power during a taper in elite swimmers. Med. Sci. Sports Exerc. 38, 1643-49.

55. De Lacey, J., Brughelli, M., Mcguigan, M., et al. (2014). The effects of tapering on power-force -velocity profilling and jump performance in professional rugby leage players. $\mathrm{J}$ Strength Cond Res. 28(12): 3567-70.

56. Hermassi, S., Ghalth, A., Schwesig, R., et al. (2019). Effects of short-term training and tapering on maximal strenght, peak power, throwing ball velocity and sprint performance in handball players. Plos One, 14 (7): E0214827.

57. Rhibi, F., Chtourou, H., Zribic, A., et al. (2016). Effect of the electrostimulation during the tapering period compared to the exponential taper on anaerobic performances and rating of perceived exertion. Sci Sports. 93-100.

58. Faria, E.W., Parker, D.L., Faria, I.E. (2005). The science of cycling. Physiology and training, part 1 . Sports Med. 35(4): 285-312.

59. Grgic, J., Mikulic, P. (2017). Tapering practices of croatian open-class powerlifting champions. J Strength Cond Res. 31(9): 2371-78.

60. Vachon A, Berryman N, Mujika I., et al. (2020). Effects of tapering on neuromuscular and metabolic fitness in team sports: a systematic review and meta-analysis. Eur J Sport Sci.14: 1-12.

61. Martin, D.T., Scifres, J.C., Zimmerman, S.D., Wilkinson, J.G. (1994). Effects of interval training and a taper on cycling performance and isokinetic leg strength. Int $\mathrm{J}$ Sports Med. 15(8):485-91.

62. Harber, M., Gallagher, P.M., Creer, A., Minchev, K.M. (2004). Single muscle fiber contractile properties during a competitive season in male runners. Am J Physiol Regul Integr Comp Physiol 287: R1124-R1131.

63. Murach, K.A., Bagley, J.R. (2015). Less is more: the physiological basis for tapering in endurance, strength and power athletes. Sports, 3, 209-18.

64. Neary, J.P., Bhambhani, Y.N., Mckenzie, D.C. (2003). Effects of different stepwise reduction taper protocols on cycling performance. Can J Appl Physiol, 28, 576-87.

65. Trappe, S., Costill, D., Thomas, R. (2000). Effect of swim taper on whole muscle and single muscle fiber contractile properties. Med. Sci. Sports Exerc. 32, 48-56.

66. Bazyler, C.D., Mizuguchi, S., Sole, C.J, et al. (2018). Jumping performance is preserved but not muscle thickness in collegiate volleyball players after a taper. J Strength Cond Res. 32(4):1020-28. 